\title{
"IMPOSSIBLE CITIZENS" IN THE GLOBAL CITY: DIONNE BRAND'S DISCOURSES OF RESISTANCE
}

\author{
Sandra Regina Goulart Almeida ${ }^{1}$ \\ Universidade Federal de Minas Gerais
}

\section{Abstract}

In both Thirsty (2002) and Inventory (2006), Dionne Brand's most recent collections of poems, the Caribbean-Canadian writer chooses to voice the dilemmas of our contemporary world, and in special the inhumanity of the global cities. The poetic voices in both collections take on the role of witnesses of this cosmopolitan world, criticizing the appalling conditions of living for some of the dispossessed and destitute subjects that live in the periphery of the global city. This work discusses how Brand addresses several ethical issues regarding the markedly global contemporary spaces that for the poet often negate most humans some form of belonging, and the means to attain agency.

Keywords: Thirsty and Inventory, discourse of resistance, globalization.

In this country where islands vanish, bodies submerge, the heart of darkness is these white roads, snow at our throats, and at the windshield a thick white cop in a blue steel windbreaker peering into our car, suspiciously, even in the blow and freeze of a snowstorm, or perhaps not suspicion but as a man looking at aliens. 
Three Blacks in a car on a road blowing eighty miles an hour in the wind between a gas station and Chatham. We stumble on our antiquity. The snow-blue laser of a cop's eyes fixes us in this unbearable archaeology.

(Brand, Land to Light On 73)

\section{Discourses of Resistance}

In the poem that opens the section entitled "Islands Vanish" from her award winning book of poems Land to Light On and cited as an epigraph to this essay, Dionne Brand offers us a striking scene that takes place in a desolate country covered by snow. What makes the episode remarkable, peculiar and, at the same time, moving is the poetic voice's awareness of how the gaze of the policeman objectifies and labels them as "aliens" and "others," thus, enclosing them in an "unbearable archaeology." Archaeology as the study of human cultures is, in this case, unbearable because it is fixed in a bipolar dynamics that subsumes, on the one hand, a system of power centered on the cop and, on the other, a possible resistance focalized on an alterity coming from the speaker and his/her Black companions. In fact, the tension depicted in such a scene pervades much of Brand's works. Her field of ideological battle to fight against injustices and prejudices, especially in Canada, as the scene above evokes, is her fictional, poetic and critical writing. In "Whose Gaze, and Who Speaks for Whom," published in the collection of essays Bread out of Stone, Brand observes:

I only draw attention here to the dominant discourse on culture in Canada. Its response to criticism from people of colour, women, lesbians and gays and progressives has been to try to assimilate a few voices into the discourse without overturning it fundamentally. Yet more vibrant possibilities exist in the multitude of voices now emerging in this country. These voices see the imagination as transformative, as 
leading out of the pessimism of colonial discourse, as making new narratives.... (131)

These new narratives emerging in the cultural scenario in Canada, Brand believes, may be able, through the articulation of a discourse of resistance, to provide a transformative perception of the world and thus change it in the long run.

Susan Sontag in her speech "On Courage and Resistance," delivered on the occasion of the ceremony that awarded the Oscar Romero prize to Ishai Menuchin in 2003, defines resistance as a concept that does not have a value in itself for it is rather its content that determines its moral necessity. Similarly to what Brand seems to evoke in the quote above, Sontag argues in favor of political activism and resistance against injustice as an ethical duty the citizen should constantly perform, even if those acts of resistance do not eventually turn into acts of justice (180-85).

Brand's comment also calls to mind Foucault's famous statement about the nature of power and resistance. For him, "where there is power there is resistance, and yet, or rather consequently, this resistance is never in a position of exteriority in relation to power" (95). For Foucault, there is an intrinsic connection between power and resistance in the sense that every act of power leads to the possibility of resistance or transgression and, as a consequence, as Sara Mills argues "no power relation is simply one of total domination" as "[e]ntailed within that relation is the force which may challenge or overthrow it" (42). Mills goes on to discuss how the very definition of the term discourse has been altered to account for the possibility of resistance: "Instead of referring to a group of statements or modes of knowing, discourse is now characterised as being open to different interpretations and thus open to resistance, even when at its most seemingly powerful" (128). Following the same line of thought, literature as a discourse becomes for Mills an important site for "contestation" of dominant discourses (25).

In Bread Out of Stone, in a chapter entitled "On Poetry," Brand voices a similar view regarding the role of poetry in her work and her 
position as an intellectual, in the sense that Said gives to the term - as a writer who has assumed the position of the intellectual who interferes in the public sphere and acts as a critical observer of society ("O papel público" 30). For Said, the contemporary intellectual knows "how to use language well" and "when to intervene in language," is someone who belongs "in the same side with the weak and unrepresented" and "whose whole being is staked on a critical sense" (Representations 2223). Viewed from this standpoint, Brand can be said to embody the contemporary intellectual who faces her world boldly and is not afraid of using her language and her profession as a means of resistance. In "On Poetry," she affirms that "it's been a relief to write poetry, it's been just room to live" because for her poetry "is here, just here. Something wrestling with how we live, something dangerous, something honest" (195-96). Poetry is, thus, her means of expressing in words the transgressive act of "watching out," of returning the impervious gaze (such as the gaze of the cop mentioned above) with another gaze, one that is critical, questioning and defiant, one that resists assimilation, appropriation, and silencing.

\section{Thirsty for Life in the Global City}

Born in Trinidad, Dionne Brand immigrated to Toronto to attend university and is now recognized as one of the most important voices in Canadian Literature - a voice that refuses to keep silence in face of injustices and prejudices. She has become known as a politically engaged writer who makes of her dense poetic writing the vehicle for a reflection on social problems such as racism, sexism, and social exclusion. Diana Brydon observes how Brand's social poetics, rather than being shaped around national themes, comes from a cultural tradition of the Black Atlantic in dialogue with Marxism, global questionings and racial and ecological issues: "Her writing performs the work of challenge and negotiation" ("Global Intimacies" 993).2

Brand's writing, in one way or another, provide a powerful critique of our contemporary world, often voiced in gender and racial terms. In 
her last two volumes of poetry - Thirsty, published in 2002, and Inventory, in 2006 - it is the global city, of which Toronto is just an example that she chooses to focus on. In these two works Brand pauses to reflect on our contemporary world and to question through her poems the exclusion of marginalized subjects that live in the periphery of contemporary global societies and market based economies.

While Brand's previous works focus on the experience of diaspora that is inherently shaped by racial and gender relations, her more recent works have shifted focus by approaching the multicultural experiences of marginalized subjects, as depicted also in What We All Long For (2005). If in the previous poems and novels Brand privileges racial issues that are central to the Canadian context, in these two books of poems the author becomes a witness of the evils and wounds of the contemporary world, making her critical voice an admirable tool to denounce the injustices suffered by the disposed. As Brydon points out, the change of focus in Brand's work from a process of mourning and melancholia associated to diasporic movements to other forms of political engagement in her more recent works, such as What We All Long For, for example, points to an important movement in Canadian postcolonial studies as well. By moving towards "new ways of connecting beyond the loyalties of the past and the potential of Toronto as a global city," Brand's characters, in Brydon's views, are closer to the multitude of Negri and Hardt than to a diasporic community ("Negotiating" 12). Brand's multitude, however, vociferates for a more just society, for the valorization of the past, and for an inclusive account of history. The global city, which becomes her favorite spatial representation through which her poetic discourse is constructed, cannot forget its past and its multi-ethnical and multicultural heritage, or its history of oppression and exclusion. As the poetic voice in Thirsty denounces tragically: "The world don't value good people/... the world doesn't love you" (13-14). Brand delineates in her more recent poems ethical and emotional issues that gravitate around the markedly global contemporary space that, for the author, negates any form of agency, belonging and locality to its dispossessed others. 
In Thirsty, the poetic voice that opens the book states "I anticipate nothing as intimate as history" (1). In fact, it is history, not only as memory of the past but also as witness of the present, that is often evoked in Brand's last volumes of poetry. Thirsty addresses the official history and the several personal histories that permeate the global city, described as being as brief as history, as the poetic voice states: "It isn't, it really isn't / the city, brief as history, / but my life in it passing sooner/ than this thirst is finished, I/" (28). The poem offer, above all, an inglorious report of human life in a global city; it describes human suffering, the many prejudices the disposed have to face, and the fear of others. The poetic voice proceeds in the same poem stating that this is her occupation, but at the moment "I/ can offer nothing except a few glances/ an uneasy sleep, a wild keening,/ it would appear nothing said matters, / nothing lived, but, this is my occupation/ One Day I will record the tenses of light,/ not now" (28). This detailed register of the "tenses of light" that the poetic voice aims to record, but sends its possibility to the future, can be found in Brand's next book of poems Inventory that, as the title suggests, presents a significant inventory of our cosmopolitan world and our geopolitical space.

Thirsty is a narrative poem that tells the story of a couple Julia and Alan, who live with Alan's mother, Chloe, and their small daughter in a Toronto described negatively as an inhospitable place, in which the family drama mingles and crashes with the indifference of the city and its inhabitants. Rather than focusing primarily on the life of this shattered and tragic family, the poems reveal the ignominy of an anonymous and solitary city, as the poem that opens the collection shows. It talks about a beautiful city, "unbreakable and amorous as eyelids," impregnated with "untrue recollections," untranslatable talks, empty conversations:

and this, we meet in careless intervals, in coffee bars, gas stations, in prosthetic conversations, lotteries, untranslatable 
mouths, in versions of what we may be,
a tremor of the hand in the realization
of endings, a glancing blow of tears
on skin, the keen dismissal in speed. (1-2)

The indifference of the city contrasts with the tragedy that involves the family when Alan is assassinated, victimized by the coward and violent act of a white police officer, generated by the irrational fear of the destitute minority: "then nothing of him but his parched body's declension/ ... saying when he had fallen, '... thirsty...'" (4). As in What We All Long For, Alan's thirst and his eager request to have it quenched as he falls dead point to the many unfulfilled desires, wishes and longings that permeate this desolate city. They also resonate Julia's desires that, as Alan's, cannot find a means of fulfillment. In poem XIII, Julia describes how she would also want to feel human as she "crave[s] of course being human as he must have":

you think of it later, falling is all you can do, as hereditary as thirst, and so of course he was thirsty, as I, craving a slake of baby's breath, or bergamot, though we were not the same, god would not be sufficient for me, nor the ache and panic of a city surprising, but thirst I know, and falling, thirst for fragrant books, a waiting peace, for life, for just halting, so I could breathe an air less rancid, live, anonymously. (22)

The only thing they can do, Julia claims, is to desire the impossible, to expect little from life and to dream of a better world. In fact, she concludes by saying that dreaming is the only act they can perform without paying anything for it: "I believe nothing, I dream but that's free" (22). Even Alan's murder, which she witnesses, remains without punishment as the policeman who is responsible for his death is acquitted of the crime, as the ironic and bitter poetic voice tells us: "a cop sashaying 
from a courthouse,/ ... light a cigar in victory of being acquitted/ of such a killing, and why not/ captured by several television networks, / ... this élan, law and outlaw, SWAT and midnight rider,/ history and modernity kissing here (48, emphasis mine). As in What We All Long For, this book of poems discusses the individual aspirations that are lost in the global city, in which people desire, more than anything, to be human. History and modernity are intermingled here in their most striking and petrifying aspect since both are witnesses to the inefficient instruments of justice and humanity.

The poetic voice privileges an overwhelming description of a city devastated by indifference and abandonment. There is neither hope nor salvation for this inhumane city, as the poetic voice denounces bluntly: "All the hope gone hard. That is a city./ The blind houses, the cramped dirty, the broken/ air ... / that is / a city, the feral amnesia of us all" (24). In many of the poems in this collection, the unnamed persona reiterates the same feeling of despair and desolation, evoking insistently the dehumanization of the global city by describing it in the following manner: "mordant," "the terror of nights," "the caustic piss of streets," "a numb symmetry" (5), "this vagrant, fugitive city" (36), "a city, as a city was supposed to be, forgetful" (60). Besides the indifference, the forgetfulness and the silencing of its peripheral citizens and his denizens, the city responds only to its so-called immediate Gods: the numerous skyscrapers, money, goods and commodities - "in the subway though these separate dreamers are a mass of silences./ They are echo chambers for the voices of the gods of cities. Glass, Money, goods" (37). The city is a space of intense interpolation and multiple frontiers: "Nothing in a city is discrete./ A city is all interpolation," in which there are too many "thresholds," "doorways," "corners" (1). It mixes with the human element to compose a space full of false recollections, untranslatable voices, ambitious and voiceless immigrants - all of them "impossible citizens / repositories of the city's panic" (40).

Similarly, in Inventory, the "earth is corroding already with cities" (40) and human beings are forced to digest everything the earth swallows: "all the materials the city stuffs in its belly" (45). Here the 
city is personified as an entity with a life, albeit a putrefied one, as a massive body that resembles so many other heartless globalized cities: "the acts of ventriloquism, the wooded arteries, / the arms clattering to the floor,/ the big raw cities flailing us" (4). At one point, referring to the same climatic conditions in several cities of the globe, the poetic voice also evokes the sameness of the dynamics that they all share: "the same in London, Chicago, Tours, Barcelona/ some rain in St. Elizabeth, Port-au- Prince deluge, / floods in Matanzas, regular day in Melbourne, São Paulo" (46). The poetic voice concludes desolately: "the physical world is not interested in us/ it does what it does/ its own inventory of time, of light and dark" (46). The personified city is not interested in human life, but, nevertheless interferes in people's lives, makes its own inventories and, instead of working for the benefit of the people in their multitude and anonymity, it simply causes pain, suffering and anguish.

The desolate description of Brand's global city diverges radically from the notion of the city as a cosmopolitan space in which citizens of the cosmos can share an ideal space of tolerance and acceptance and in which the will and the well-being of the majority is preserved, as the historical notions of the Cosmopolis that Kant and other philosophers of the antiquity refer to (Appiah xiv-xx). In this sense, both in Thirsty and in Inventory, the city becomes the personification of an agent of globalization, a predatory and an accomplice that is blind to people's suffering because "the cities wear bandages over the eyes" (43), not as a sign of justice that provides the same rights to all citizens and does not distinguish among them, but rather as a sign of refusal to see and to testify against the crimes and injustices of our time.

\section{Inside the Global City}

Brand's poems address many of the issues discussed by Saskia Sassen about the global city and the spatial category in our contemporary world. She claims that the global city is a strategic space to think about the economic globalization of the historical moment we 
now live in, as Brand's collections of poems discussed here demonstrate. Sassen argues that the city theorized today is quite different from that of the past because national economies are becoming less differentiated and more globalized, as the several economic turbulences of the past years that have caused enormous social and economic consequences have confirmed (Sassen, Globalization ixx-xx). In her renowned work The Global City (2001), the author calls attention to the way the social order is deeply affected by the new geopolitical configuration and economic polarization of the present. She recognizes that the global city is a strategic space for peripheral and marginalized subjects because it often allows them to be present and to be perceived as subjects of this new configuration, but this same structure excludes these subjects from social relations and the possibility of empowerment. Sassen highlights the growing asymmetry caused by the social composition of the global city because of economic polarization that benefits the higher income stratum while it deteriorates the condition of workers in the lower stratum (The Global City 9-14). For Sassen, two developments have contributed for this polarization:

One is the vast supply of low-wage jobs required by highincome gentrification in both its residential and commercial settings.... A second... is what I call the downgrading of the manufacturing sector, a process in which the share of unionized shops declines and wages deteriorate while sweatshops and industrial homework proliferate. (The Global City 9)

This is what Sassen refers to as a "geography of centrality" as opposed to a "geography of marginality." For her, these contradictory spaces coexist paradoxically in the global city (Globalization xxvi) that Brand portrays in her more recent poems. Zygmunt Bauman endorses such view by stressing that one of the characteristics of the process of globalization nowadays is a progressive spatial segregation and a progressive separation and exclusion of peoples (9). Silviano Santiago, 
following the same logic proposed by Sassen and Bauman, calls attention to an inherent phenomenon of what he calls a "cosmopolitism of the poor" that he observes in this unstable global village (51). The author argues that contemporary cosmopolitism and multiculturalism created a different form of inequality that goes beyond the nation by encouraging the marginalized subject to act as transnational agents, but clandestine ones that are recruited simply as instruments to maintain the economic system that runs the postmodern global city (51-59). These are, in fact, the "ambitious immigrants," anonymous agents, "untranslatable mouths," the transient selves, and "the impossible citizens" that Brand depicts so well. These "impossible citizens" can be viewed as the "clandestine passengers of the insane vessel of postmodernity" that for Santiago follow the "flux of transnational capital as sunflowers" (52). Or as Brand's inventory registers: the global city preserves and intensifies the structure of exclusion as the rich become richer and poverty is multiplied - "but nothing happens/ the wealth multiplies in the garbage dumps, / and the quiet is the quiet of thieves" (40).

Discussing the cultural dimension of globalization in Modernity at Large, Arjun Appadurai also draws attention to the role these marginalized and destitute subjects have in the construction of contemporary localities: "The many displaced, deterritorialized, and transiet populations that constitute today's ethnoscapes are engaged in the construction of locality, as a structure of feeling, often in the face of the erosion, dispersal, and implosion of neighborhoods as coherent social formations" (Modernity 199). In his more recent work, Fear of Small Numbers (2006), Appadurai chooses precisely these dislocated communities that are marginalized and disempowered as object of his theorization, as does Brand in the collection of poems discussed here. The author addresses the new geographies of anger and fear that trigger contemporary violence, frequently generated by the excessive hatred against destitute minorities. What Appadurai refers to as anxiety of incompleteness is caused by "the uncertainties about identity that global flows invariably produce" (Fear 7): 
Numerical majorities can become predatory and ethnocidal with regard to small numbers precisely when some minorities (and their small numbers) remind these majorities of the small gap which lies between their condition as majorities and the horizon of an unsullied national whole, a pure and untainted national ethos. (Fear 8)

This fear derives from the uncertainty and the difficulty of establishing and delineating the distance that separates "we" and "them." For Appadurai, the predatory identities, which are fomented by the dialectics of we/they, are precisely those that require "the extinction of another collectivity for their own survival" and, facing the narcissistic wounds (theorized by Freud) that are characteristic of this group, convert these wounds into the fear of a disempowered minority (Fear51,83). The critic also highlights how this violence and fear that is directed towards the minorities - the small numbers of his title - can be envisioned in the abuse of the bodies of these marginalized subjects: "The body, especially the minoritized body, can simultaneously be the mirror and the instrument of those abstractions we fear most" (Fear 47).

Sara Ahmed, in turn, argues that there is an intrinsic relation between space and mobility in the organization of fear that creates collectivities around a common feeling (68). The global politics of fear, for Ahmed, presupposes a constant threat that generates fear (70-72). Rather than making the bodies shrink, as one might expect, fear allows bodies "to occupy more space through the identification with the collective body" that acts and moves on its behalf (74). In this sense, Ahmed states, fear ends up expanding the mobility of some bodies at the same time that it limits the movement of others, less powerful or less articulated ones (79).

Brand's poetry collections can, therefore, be viewed as an important vehicle to reflect upon several of theorizations proposed above. They also perform the function of chronicling the vicissitudes of the global city, the many geographies of fear of our contemporary world, and the place 
and space occupied by human beings, especially the disempowered ones in the desolating scenario that she depicts in her work.

\section{An Inventory of the World}

Brand's city in both Thirsty and Inventory mirrors precisely the paradoxical global metropolis described in theoretical terms by Sassen, Santiago and Appadurai. It is a city that is divided into opposite and contradictory poles, into collectives that oppose each other, into those that threaten and those that are intimidated, that is, into the geographies of centrality and marginality, which Sassen discusses. It is, furthermore, a city that faithfully portrays the concept of geography of fear proposed by Appadurai. The poetic voices in both works emblematically associate themselves with the marginal and disempowered subjects about whom the critics above talk. The bodies of these "small numbers" are depicted as the material evidence of the indifference, alienation and fear observed in the global city, as the following poem shows:

nothing, in the city there is nothing simple, or simple fidelity, the heart is slippery, the body convulsive with disguises abandonments, everything is emptied wrappers, coffee cups, discarded shoes, trucks, street corners, shop windows, cigarette ends, lungs, ribs, eyes, love, the exquisite rush of nothing, the damaged horizon of skyscraping walls, nights insomniac with pinholes of light. (Thirsty 5)

The body, in this poem, as in other parts of both Thirsty and Inventory, appears "as an affective anchor," since, as Jeff Dersen stresses, "the body figures centrally in Brand's geopolitical landscape" (20). The hidden, abandoned, wounded body in Brand's poems becomes the 
object through which repression and violence are enacted. The subjects who suffer victimization through the body vociferate against its exploitation and demand a more humane and compassionate space in which they can inhabit. They are thirsty and long for more humanity.

In Inventory, the body is objectified in face of the destruction of humanity: "we arrived spectacular, tendering/ our own bodies into dreamery, / as meat, as mask, as burden" (3). In another moment, city and body are conflated becoming a sole being in a conflictive interaction: "machine and body, shield and tissue,/ the highway worked itself into her shoulders / and neck, now she was trembling, tasting/ all the materials the city stuffs in its belly" (45). As Diana Brydon observes, in Inventory, the injustice suffered is located in the body as a form of testimony: "Each shock is registered in the poet's body" ("Global Intimacies" 997).

Thirsty highlights first and foremost the pungent testimony of human suffering in face of the anonymity in the global city: "A house in this city is a witness box/ of every kind of foolishness" (54). Alan, before his death, preached a litany that resembles the inventories that will later appear in the next book of poems: "All the dreadfulness that happened in America had happened, / his inspired sermons at Christie Pits steamed,/ ... all this dreadfulness had come home to him" (14).

In Inventory, humanity is directly summoned to render accounts of the devastation of the planet and the annihilation of the many others we fear. The poetic voice accuses humanity of having caused a meaningless destruction of the planet: "we exhausted so much on useless destruction" (67). Brydon observes how Brand's work has moved from a characteristically politics of resistance to one that assumes the co-option and the complicity with our present geopolitical scenario "while refusing to give up an alternative vision" ("Global Intimacies" 996). The poetic voice refuses to let us forget our own complicity in the present historical moment of destruction and extermination: "let's at least admit we mean each other/ harm, / we intend to do damage" (42). The dialectics of we/them proposed by Appadurai is here diluted 
for the poetic voice clearly argues that "we" - and not only "they" are also responsible for the wounds of our time and spaces: "so hard now to separate what was them/from what we were/ how imprisoned we are in their ghosts" (8-9). And in another poem: "we,/ there is no 'we' / let us separate ourselves now, / though perhaps we can't, still and again/ too late for that, nothing but to continue" (42). In fact, a powerful critique is delineated as the poetic voice positions herself as a spy and a terrorist, as someone that can simultaneously side with the others, acting on their behalf, be their accomplice or destroy them in a terrorist act: "take this letter, put it on your tongue,/ sleep while I keep watch,/ know that I am your spy here, your terrorist,/ find me" (37). The word terrorist here is invested with a double meaning as it points to someone who threatens and causes terror, in Ahmed's views, but not only for wanting to destroy but also for claiming to do so with the aim of protecting some against others - to save some necessarily means to destroy others that are not part of the community to be protected, as Appadurai would argue.

The inventory to which the title alludes is compiled by a woman that, like Brand, makes use of the language, poetry and writing as a form of testimony and protest: "everybody grows perversely accustomed/ she refuses" (29), "she's written a letter,/ an account of her silence,/ its destination all the streets" (34). For the poetic voice of this long poem, our world provides the elements of this sad story to be told as "this big world is the story, I don't have any other" (84). In the final poem, she affirms gloomily that the story she tells will not bring comfort. But rather, it will be a disheartening and discouraging account of our world: "I have nothing soothing to tell you,/ that's not my job, / my job is to revise and revise this bristling list,/ hourly" (100).

Brand's persona may not be able to offer redemptive solutions, but she exposes, questions, problematizes and, above all, accounts for the historical legacy of our contemporary world in face of the atrocities witnessed and the pervasive complicity of mass media. Poetry becomes then an important political tool to regain the public sphere as a terrain 
of debate, discussion and protest against the perpetration of injustices and prejudices (Brydon, "Global Intimacies" 990).

Brand's poetic voices lament the present state of humanity and question the lack of communication among peoples despite the great advances in media and communication technologies. Humanity suffers and becomes more destructive, fomenting the collective fear and intolerance against each other, thus originating many versions of Appadurai's predatory identities. Brand's poetic voices resonates the necessity of an ethical positioning regarding the testimony we all give of this contemporary world. In the same way that Spivak delineates a new connotation for the concept of planetarity, by opposing it to globalization, emphasizing the alterity and the humanity of the planet in opposition to the construction and artificiality of the globe (72), Brand tries to transform our globalized cities in more humanized spaces - or, as Massey would argue in geographies of allegiance, that is, in spaces marked by a profound interpersonal and selective attachment (19). The rigidity of the globe is opposed to the humanity of the planet, which, in turn, allows us to think, as Brydon claims, in affective citizenships and emotive geographies in which affect and emotion predominate as categories of affiliation and connection to other possible geographies ("Global Intimacies" 999-1000).

Brand seems to offer us only the hope of a better world for at the moment she has nothing comforting to tell us: "I have nothing soothing to tell you/that's not my job" (100). While we wait, Brand seems to tell us, we should avoid being like Santiago's sunflowers that simply follow the global flux instinctively. We should, on the contrary, question and interrogate not only the situation of the world we live in, but also our own accountability and compromise with the present state. For Brand, we should fight with the weapons we have, in this case, with words, poetry and discourses of resistance, aware of the fact that we are all witnesses, and also accomplices, of the historical legacy of humanity that we leave to other generations. 


\section{Notes}

1 This work is part of a research sponsored by the funding agencies $\mathrm{CNPq}$ and FAPEMIG.

2. See also: Almeida, "Os inventários da cidade global de Dionne Brand" 187-200.

\section{References}

Almeida, Sandra Regina Goulart. "Os inventários da cidade global de Dionne Brand." Migrações teóricas, interlocuções culturais: estudos comparados (Brasil/Canadá). Eds. Sandra R. G. Almeida, Dilma C. B. Diniz, José dos Santos. Belo Horizonte: Argvmentvm, 2009. 187-200.

Ahmed, Sara. The Cultural Politics of Fear. London: Routledge, 2004.

Appadurai, Arjun. Fear of Small Numbers: An Essay on the Geography of Anger. Durham: Duke UP, 2006.

. Modernity at Large: Cultural Dimensions of Globalization. Minneapolis: Minnesota UP, 1996.

Appiah, Kwame Anthony. Cosmopolitanism: Ethics in a World of Strangers. London and New York: Norton, 2006.

Bauman, Zygmunt. Globalização: as conseqüências humanas. Trad. Marcos Penchel. Rio de Janeiro : Jorge Zahar, 1999.

Brand, Dionne. Bread out of Stone: Recollections on Sex, Recognitions, Race, Dreaming and Politics. Toronto: Vintage Canada, 1994.

. Fierce Departure: The Poetry of Dionne Brand. Waterloo, Canada: Wilfrid Laurier UP, 2009.

. Inventory. Toronto: McClelland \&Stewart, 2006.

. Land to Light on. Toronto: McClelland \&Stewart, 1997.

. Thirsty. Toronto: McClelland \&Stewart, 2002. 
. What We All Long For. Toronto: Knopf, 2005.

Brydon, Diana. "Canadian Writers Negotiating Home Within Global Imaginaries." <http:// myuminfo.umanitoba.ca/Documents/852/NegotiatingHome.pdf>. 7 Ago. 2009.

. “Dionne Brand's Global Intimacies: Practising Affective Citizenship." University of Toronto Quarterly 76.3 (2007): 990-1006.

Derksen, Jeff. "National Literatures in the Shadow of Liberalism: Dionne Brand's Geopolitical Landscape." <http://www.transcanadas.ca/media/pdfs/ derksen.pdf> 3 Ago 2009.

Foucault, Michel. The History of Sexuality: The Uses of Pleasure. Vol. 2. London and New York: Penguin, 1984.

Massey, Doreen. World City. London: Polity, 2007.

Mills, Sara. Discourse. London and New York: Routledge, 1997.

Said, Edward. "O papel público de escritores e intelectuais." Combates e utopias. Org. Denis Moraes. Rio de Janeiro: Record, 2004. 25-50.

_. Representations of the Intellectual. New York: Vintage, 1994.

Santiago, Silviano. O cosmopolitismo do pobre. Belo Horizonte: Editora UFMG, 2004.

Sassen, Saskia. Globalization and Its Discontents: Essays on the New Mobility of People and Money. New York: The New Press, 1998.

. The Global City: New York, London, Tokyo. $2^{\text {nd }}$ Edition. Princeton: Princeton UP, 2001.

Sontag, Susan. At the Same Time: Essays and Speeches. London and New York: Farrar, Straus, and Giroux, 2007.

Spivak, Gayatri Chakravorty. Death of a Discipline. New York: Columbia UP, 2003. 